\title{
Medication Distribution
}

National Cancer Institute

\section{Source}

National Cancer Institute. Medication Distribution. NCI Thesaurus. Code C128536.

The distribution, sale, or transfer of a drug not pursuant to a specific prescription. 